\title{
Correction to: Prognostic significance of preoperative plasma D-dimer level in patients with surgically resected clinical stage I non-small cell lung cancer: a retrospective cohort study
}

\author{
Kaoru Kaseda ${ }^{1 *}$, Keisuke Asakura', Akio Kazama ${ }^{2}$ and Yukihiko Ozawa ${ }^{3}$
}

Correction to: J Cardiothorac Surg

https://doi.org/10.1186/s13019-017-0676-3

The original version of this article [1] did not cite the following sources [2-5], which were used to write the article.

The authors apologise for any inconvenience that this might have caused.

\footnotetext{
Author details

${ }^{1}$ Department of Thoracic Surgery, Sagamihara Kyodo Hospital, 2-8-18 Hashimoto, Midori-ku, Sagamihara, Kanagawa 252-5188, Japan. ${ }^{2}$ Department of Pathology, Sagamihara Kyodo Hospital, 2-8-18 Hashimoto, Midori-ku, Sagamihara, Kanagawa 252-5188, Japan. ${ }^{3}$ Yuai Clinic, 1-6-2 Kitashinyokohama, Kohoku-Ku, Yokohama, Kanagawa 223-0059, Japan.
}

Received: 13 June 2019 Accepted: 13 June 2019

Published online: 20 June 2019

\section{References}

1. Kaseda K, Asakura K, Kazama A, Ozawa Y. Prognostic significance of preoperative plasma D-dimer level in patients with surgically resected clinical stage I non-small cell lung cancer: a retrospective cohort study. Cardiothorac Surg. 2017;12(1):102.

2. Fukumoto K, Taniguchi T, Usami N, et al. The preoperative plasma D-dimer level is an independent prognostic factor in patients with completely resected non-small cell lung cancer. Surg Today. 2015:45:63.

3. Jiang $H G$, Li J, Shi SB, et al. Value of fibrinogen and D-dimer in predicting recurrence and matastasis after radical surgery for non-small cell lung cancer. Med Oncol. 2014;31:22

4. Kaseda K, Watanabe K, Asakura K, Kazama A, Ozawa Y. Identification of falsenegative and false-positive diagnoses of lymph node metastases in nonmall cell lung cancer patients staged by integrated 18F-fluorodeoxyglucose positron emission tomography/computed tomography: A retrospective cohort study. Thorac Cancer. 2016;7:473-80.

5. Kaseda K, Asakura K, Kazama A, Ozawa Y. Clinicopathological and prognostic features of surgically resected pathological stage I lung adenocarcinoma

\footnotetext{
*Correspondence: kaseda@wb4.so-net.ne.jp

${ }^{1}$ Department of Thoracic Surgery, Sagamihara Kyodo Hospital, 2-8-18

Hashimoto, Midori-ku, Sagamihara, Kanagawa 252-5188, Japan

Full list of author information is available at the end of the article
}

harbouring epidermal growth factor receptor and K-ras mutation. Thorac Cancer. 2017;8:229-37.

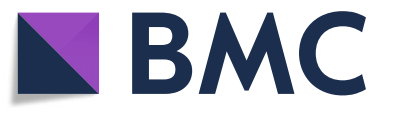

(c) The Author(s). 2019 Open Access This article is distributed under the terms of the Creative Commons Attribution 4.0 International License (http://creativecommons.org/licenses/by/4.0/), which permits unrestricted use, distribution, and reproduction in any medium, provided you give appropriate credit to the original author(s) and the source, provide a link to the Creative Commons license, and indicate if changes were made. The Creative Commons Public Domain Dedication waiver (http://creativecommons.org/publicdomain/zero/1.0/) applies to the data made available in this article, unless otherwise stated. 